\title{
Yield Potential of Spring Wheat Influenced by Crop Residue, Tillage System and Nitrogen Rate on Irrigated Land
}

(Potensi Hasil Gandum Musim Bunga yang Dipengaruhi oleh Sisa Tanaman, Sistem Bajakan dan Kadar Nitrogen di Tanah Sawah)

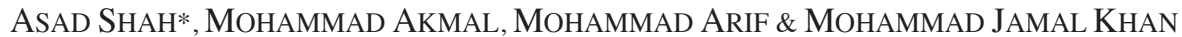

\begin{abstract}
Yield performance in wheat (Triticum aestivum) was compared under crop residue, tillage system and nitrogen rate treatments in cereal based cropping system. The experiments were conducted at Agronomy Research Farm, The University of Agriculture, Peshawar, in 2009-2010 and 2010-2011. Chopped crop residue on dry matter basis (5 tha ${ }^{-1}$ ) of legume (Vigna unguicuata, var. Ebney) and cereal (Zea mays, var. Azam) was applied in main plots with no residue treatments and plowed with Mould Board (MB) and Cultivator as deep and shallow treatments, respectively. A month after the crop residue and tillage system treatments, field was uniformly plowed with cultivator and wheat was sown with drill in rows $25 \mathrm{~cm}$ apart in the month of November on both years. Both $\mathrm{P}_{2} \mathrm{O}_{5}$ and $\mathrm{K}_{2} \mathrm{O}\left(80\right.$ and $40 \mathrm{~kg} \mathrm{ha} \mathrm{g}^{-1}$, respectively) were applied uniformly to all fields before sowing. Nitrogen as subplot treatment $\left(0,40,80,120\right.$ and $\left.160 \mathrm{~kg} \mathrm{ha}^{-1}\right)$ was applied in two splits, half at 15 and the other half at 45 days after sowing with uniform cultural practices for crop growth and development. Compared to year 1, crop of year 2 showed better phenology with extended life cycle (LC). On two years average across tillage and $N$ treatments, biological yield did not change $(\mathrm{p}<0.05)$ under the residue but did report lower at no-residue treatment. Nonetheless, grain yield showed a significant $(\mathrm{p}<0.05)$ change with the highest in legume followed by cereal and the lowest in no-residue treatments. A non-significant tiller number and significant variations in grain weight and spike $m^{-2}$ were observed that influenced the grain and biological yield differently. Deep than shallow tillage resulted in better traits, which returned better biomass and grain yield. Nitrogen application from control to every increment showed a significant $(\mathrm{p}<0.05)$ improvement in all observations contributing in yield. The study confirms the significance of legume vs. cereal over no-crop residue incorporated through deep tillage system with optimum $N$ (120 $\mathrm{kg} \mathrm{ha}^{-1}$ ) in cereal-based cropping system for sustainable performance to sustain soil C:N for future production.
\end{abstract}

Keywords: Cereals legume residue; tillage system and N rates; vegetative and reproductive days; wheat yield; yield traits

ABSTRAK

Prestasi hasil gandum (Triticum aestivum) dibandingkan antara sisa tanaman, sistem bajakan dan kadar rawatan nitrogen dalam sistem tanaman berasaskan bijirin. Uji kaji ini telah dijalankan di Ladang Kajian Agronomi, Universiti Pertanian, Peshawar pada 2009-2010 dan 2010-2011. Sisa keratin tanaman berasaskan bahan kering (5 tha $\left.{ }^{-1}\right) k_{\text {ekacang }}$ (Vigna unguicuata, var. Ebney) dan bijirin (Zea mays, var. Azam) digunakan dalam plot utama dengan rawatan tiadasisa dan dibajak dengan acuan sepak (MB) dan penggembur masing-masing sebagai rawatan dalam dan cetek. Sebulan selepas rawatan sisa tanaman dan sistem bajakan, padang dibajak secara seragam dengan penggembur dan gandum dicambah dengan gerudi dalam baris jarak $25 \mathrm{~cm}$ pada bulan November pada kedua-dua tahun. Kedua-dua $P_{2} \mathrm{O}_{5}$ dan $\mathrm{K}_{2} \mathrm{O}$ (masing-masing 80 dan $40 \mathrm{~kg} \mathrm{ha}^{-1}$ ) digunakan secara seragam untuk semua padang sebelum semaian. Nitrogen digunakan sebagai rawatan subplot (0, 40,80, 120 dan $\left.160 \mathrm{~kg} \mathrm{ha}^{-1}\right)$ dalam dua pecahan, separuh bahagian pada hari ke-15 dan separuh lagi pada hari ke-45 selepas amalan menyemai secara lazim untuk pertumbuhan dan perkembangan tanaman. Berbanding dengan tahun 1, tanaman tahun 2 menunjukkan fenologi yang lebih baik dengan kitaran hidup lanjutan (LC). Dalam purata dua tahun rawatan $N$ dan bajakan hasil biologi tidak berubah $(\mathrm{p}<0.05)$ bagi rawatan sisa tetapi lebih rendah pada rawatan tiada-sisa. Walau bagaimanapun, hasil bijirin menunjukkan perubahan yang signifikan $(\mathrm{p}<0.05)$ dengan yang tertinggi adalah dalam rawatan kekacang diikuti oleh bijirin dan yang paling rendah dalam rawatan tiada-sisa. Jumlah tiler tidak signifikan dan variasi signifikan dalam berat bijirin dan merejam $m^{-2}$ diperhatikan mempengaruhi bijirin dan hasil biologi berbeza. Bajakan daripada cetek menghasilkan sifat seterusnya yang lebih baik dan memberi pulangan yang lebih baik dalam hasil bijirin. Aplikasi nitrogen daripada kawalan untuk setiap kenaikan menunjukkan peningkatan yang signifikan $(\mathrm{p}<0.05)$ dengan semua pemerhatian menyumbang kepada hasil. Kajian ini mengesahkan kepentingan kekacang vs bijirin daripada tanaman tiada-sisa yang dimasukkan melalui sistem bajakan dengan optimum N (120 kg ha $\mathrm{kg}^{-1}$ bagi sistem berasaskan bijirin untuk mencapai prestasi yang mapan dalam mengekalkan tanah $C: N$ untuk pengeluaran pada masa hadapan.

Kata kunci: Hasil gandum; hari vegetatif dan pembiakan; sifat hasil; sisa bijirin kekacang; sistem bajakan dan kadar N 


\section{INTRODUCTION}

Wheat, a staple diet of Pakistan, is planted annually on the highest cropped area. It is one of the most important winter crops, which contributes $12.5 \%$ to the value added in agriculture and $2.6 \%$ to national GDP (ESP 2012). Wheat production in the country has increased considerably since 1960s due to increase in arable area, introduction of the yielding varieties, nitrogen fertilizer and adopting effective agronomic measurements (FAOSTAT 2012). Food security of the country is at a risk due to rapid increase in the population (FAO 2009). It is expected that by the year 2050, total population is expected to cross the figure 0.27 billion from the existing 0.18 billion (ESP 2012; UNPD 2011), which may owe their existence to synthetic $\mathrm{N}$ fertilizers (Smil 2011; UNWPP 2012). The widespread adoption of $\mathrm{N}$ fertilizers has boosted the food productivity. Currently, the increase in population can either be fed by supply of adequate amounts fulfilling the crop nutrients demands i.e. the $\mathrm{N}$ throughout the growing season and substantially increase yields (Silvester-Bradley 1993). From 1961 to 1996, generally the world cereal grain production has shown an annual increment of about $4.1 \%$ (Mosier et al. 2001), of which only $40 \%$ is attributed to increase in productivity by $\mathrm{N}$ fertilizers (Brown 1999). Adoption of the $\mathrm{N}$ fertilizers has also increased the overall farm yield. Before the advent of $\mathrm{N}$ fertilizers, it was typical to maintain $25-50 \%$ fertility of a farm in a legume-rich pasture or cover crop that has regenerated soil fertility through biological fixation of atmospheric $\mathrm{N}$ and the buildup of slowly weathered nutrients in plant biomass (Smil 2001). An increasing number of the people also think that our global food system is rapidly approaching the optimum. Under such conditions, conversion of the sustainable agriculture is essential to sustain life in the region.

Sustainable farming system can be maintained through adequate soil and crop management for increase in production through restoring soil fertility (Pathak et al. 2003). For sustainable production of soil, the crop residue incorporation has increased production fourfold from 11 to 37 Mha in a decade (IFOAM 2012). Crop residue, traditionally considered a trash or agricultural waste, includes corn stalks, corn cobs, wheat straw and other leftovers from grain crops are now being viewed as a resource with economic value. If the current trend continues, crop residue is and will be a valuable product of the grain crop in agriculture management system (Hofstrand 2009). Appropriate incorporation of the crop residues has increased rate of organic matter in the soil (Teixeira et al. 2009) that could ensure availability of the global food grain production (Karlen et al. 2009). Crop residue returns fertility back to the soil. It is estimated that harvest of the residue has removed 20 pounds of nitrogen, 2.9 pounds phosphate and 25 pounds potash per ton of dry matter (Edwards 2007). Tillage in combination with residue has a close association in efficient and effective decomposition of organic matter into the soil with increased in fertilizer application efficiency (Bhagat
1990). Besides ensuring a sustainable productivity, the residue management can be an integral part of the future food security in regions where population is increasing and soil organic matter is depleting. Appropriate decomposition of the crops residue with proper tillage system has been reported to increase in yield (Strudley et al. 2008).

Useful to know is the yield potential of a major crop e.g. wheat annually grown on a $40 \%$ cropped area through residue management of legume and cereals vs. no residue (Fillery 2001). We intend to know yield variations under the nitrogen rates with and without residue of cereals and legume of different nature on a cereal based rotation system.

\section{MATERIALS AND METHODS}

Field experiments were conducted at Agronomy Research Farm, the University of Agriculture Peshawar-Pakistan in 2009-2010 and 2010-2011. The experimental site is located $350 \mathrm{~m}$ above sea level at Peshawar $\left(17^{\circ}, 35^{\prime} \mathrm{N}\right.$ and $35^{\circ}, 41^{\prime}$ $\mathrm{W})$ with main cropping system of wheat-maize-wheat. Soil of the experimental site is clay loam, deficient in mineral $\mathrm{N}$ ( $<8.2 \mathrm{mg} \mathrm{kg}^{-1}$ soil), $\mathrm{P}_{2} \mathrm{O}_{5}\left(<20 \mathrm{mg} \mathrm{kg}^{-1}\right.$ soil) with adequate $\mathrm{K}_{2} \mathrm{O}\left(>120 \mathrm{~g} \mathrm{~kg}^{-1}\right.$ soil). The soil has a $\mathrm{pH} 7.9$ and organic matter content less than $1 \%$. Climate of the area is warm to hot, semi-arid subtropical receiving $<500 \mathrm{~mm}$ annual precipitation with daily mean temperatures varying from $45 \pm 4^{\circ} \mathrm{C}$ in summer to $10 \pm 3^{\circ} \mathrm{C}$ in winter.

A total of 30 treatments (i.e. three crop residues, two tillage practices and five $\mathrm{N}$ fertilizer rates) each replicated four times were studied for two crop growth seasons. The experiments were conducted in a randomized complete block design having split-plot arrangement. The residues treatments (i.e. no residue, legume residue and cereals residue each applied $5 \mathrm{t} \mathrm{ha}^{-1}$ ) and tillage treatments (i.e. shallow tillage using cultivator vs. deep tillage using Mould bold plow) were assigned to the main plot and nitrogen rates (i.e. $0,40,80,120$ and $160 \mathrm{~kg} \mathrm{ha}^{-1}$ ) to the subplot. The main plot was maintained as $17 \times 4 \mathrm{~m}$ and subplot 3 $\times 4 \mathrm{~m}$, accommodating 16 rows at $25 \mathrm{~cm}$ equal distances. A demarcation $0.5 \mathrm{~m}$ was also maintained between main plots and sub plots. Wheat (Triticum aestivum) basic seeds (cv. Pirsabak 2005) were obtained from Cereal Crop Research Institute (CCRI), Pirsabak, Nowshera. Crop residues of cowpea (legume Vigna unguicuata var. Ebney) and maize (cereal Zea mays var. Azam) were collected from summer season crop harvested at the farm. The semidried crop residues were chopped 3-5 cm in length on an electric chopper. Based on dry matters, desired quantity was spread in respective experimental units. The $\mathrm{C}$ and $\mathrm{N}$ ratios of crop residues (cow pea and maize) at the time of incorporation were $31: 1,31: 1$ and $81: 1,71: 1$ during the crop seasons 2009-2010 and 2010-2011, respectively. The respective main plots were subsequently plowed with a Mould bold plow as deep tillage (45 $\mathrm{cm}$ depth) and with a cultivator as shallow tillage (15 cm depth). Each plow was run twice across the field. Subsequent irrigation of the field 
was given after plowing to ensure rapid decomposition. During seedbed preparation, the entire field was plowed with cultivator followed by planking. Planting was done on November 23, 2009 and November 15, 2010 with the automatic tractor drawn drill spaced uniformly rows at $25 \mathrm{~cm}$ distance and $2.5 \mathrm{~cm}$ depth. Uniform seed rate $\left(120 \mathrm{~kg} \mathrm{ha}^{-1}\right.$ ) was used. Phosphorus and potash were applied at seedbed preparation at the rate of 80 and 40 $\mathrm{kg} \mathrm{ha}^{-1}$, respectively, using single super phosphate $(18 \%$ $\left.\mathrm{P}_{2} \mathrm{O}_{5}\right)$ and murate of potash $\left(60 \% \mathrm{~K}_{2} \mathrm{O}\right)$ sources. Nitrogen fertilizer was applied from urea $(46 \% \mathrm{~N})$ source in two split applications as pre treatment requirements, half after emergence and half 45 days after sowing as strip application in between the rows. Recommended cultural practice e.g. irrigation, weeding and hoeing (manually) was applied throughout the crop growth as per crop demands. During growth, observations were recorded on days to emergence, days to anthesis and days to maturity by counting days taken from planting to $50 \%$ plants produced the respective traits in an experimental unit. Tiller and spike $\mathrm{m}^{-2}$ was recorded by counting tiller number in 0.5 $\mathrm{m}$ row at three places in an experimental unit at harvest and averaged for a mean value. The data was converted to tiller and spike $\mathrm{m}^{-2}$, respectively. The grains per spike data was recorded by counting grains in 25 randomly selected spikes in each experimental unit and averaged for a single value. Thousand grains weight was recorded by weighing thousand grains at a stable balance. The biological yield was recorded by harvesting six central rows from an experimental unit, sun dried in the farm, weighed and converted to $\mathrm{kg} \mathrm{ha}^{-1}$. The grain yield was recorded in six central rows, harvested for biological yield in an experimental unit and threshed for grain yield. The harvest index was calculated as ratio of the grain to biological yield.

Analysis of variance (ANOVA) technique was used to detect significance effect of the applied treatments on observed parameters. Data from both years were analyzed together and treatment values were expressed as mean of the two seasons. In case of significant difference, LSD test and standard error of means (Steel \& Torrie 1997) were used to separate by computer software (SAS Institute 2011).

\section{RESULTS}

Data on growth, yield and yield related traits of the two crop seasons are presented in different columns (Table 1), the correlation coefficient matrix of the yield traits (Table 2) and interactive effects of treatments (Figures 1 to 4 ) has shown a significant $(p<0.05)$ response, respectively. Among the crop phenology, 2010-2011 crop was observed with a longer life cycle (LC) than the crop 2009-2010 and hence resulted in a significantly extended both vegetativeday (VD) and reproductive-day (RD). A similar response was observed for the crop residue treatments on LC, VD and $\mathrm{RD}$, with the highest under legume, followed by cereals and the lowest at no residue (Table 1). Deep over the shallow tillage extended LC with longer VD and RD. Nitrogen as treatments showed the longest $\mathrm{LC}$ as well both VD and RD under the highest application rate $\left(160 \mathrm{~kg} \mathrm{ha}^{-1}\right)$, which subsequently decreased the crop LC, VD and RD when N was reduced from $160 \mathrm{~kg} \mathrm{ha}^{-1}$ at every step down rate of the applied treatment to the lowest in control.

Among the yield traits, second season crop out yielded both the tiller number and productive tillers i.e. the spikes per unit area, grain number per spike and thousand grains weight. Consequently, it reflected higher $(p<0.0 \%)$ grain, biological yield with a better harvest index over the first season crop. Crop residue application of either nature did not differ but did differ than no residue in total tiller number per unit area. Nonetheless, legume residue showed the highest productive tiller than cereal residue $(p<0.05)$ and the cereals than no residue treatments with significant differences from each other. Grain per spike was reported the highest under legume with a non-significant change in cereals and no residue treatments. However, the unit grain weight did show significantly positive changes from no residue to cereals and the highest under legumes residue. This reflected a similar response on grain yield with the highest for legume, followed by cereals and the lowest for no residue treatments. Biological yield in either residue was the same but the lowest $(p<0.05)$ in no residue treatment. Harvest indices significantly improved from no residue to cereals and from cereals to legume residue applications. Deep than shallow tillage system showed a significant reduction in all yield traits and yield including the harvest index. Likewise, all the observed yield traits including the grain and biological yield showed a significant increment, when $\mathrm{N}$ was applied at every higher rate over the control (0) to the maximum $\left(160 \mathrm{~kg} \mathrm{ha}^{-1}\right)$ application rates. Harvest index did not differ at 160 and $120 \mathrm{~kg} \mathrm{ha}^{-1}$ but did show a significant $(p<0.05)$ reduction when $\mathrm{N}$ application to the crops declined with the lowest in the control (0) treatment. Between the grain yield and its individual traits, there was a strong association observed when regressed with each other (Table 2). This association was observed stronger within and among the traits with strong positive correlation for two years average data of the experiments.

Interactive effects of the treatments (crop residue $x$ tillage) did vary significantly for the VD, RD, grain yield and HI only (Figure 1). Deep than shallow tillage system out yielded the VD in a relatively stable fashion with an increasing trend from no residue to cereal residue and from cereals to legume residue. Contrary to that, RD showed a minute difference for deep versus shallow tillage system at no residue, almost the same at cereal residue and a relatively moderate difference at legume residue treatment. Grain yield did vary for the treatment on no residue application between deep and shallow tillage system with almost a matching readings at either residue applications but higher for the legume than cereal. Harvest index was differed in shallow and deep tillage system at no residue but quite similar at either residue but with the highest for the legume than cereal. Interactive effects of 
TABLE 2. Combined Pearson correlations among different parameters recorded for wheat planted under the treatments residue, tillage and $\mathrm{N}$ rates

\begin{tabular}{|c|c|c|c|c|c|c|c|c|c|c|}
\hline Parameters & VD & $\mathrm{RD}$ & $\mathrm{LC}$ & $\mathrm{Tm}^{-2}$ & $\mathrm{Sm}^{-2}$ & $\mathrm{GS}^{-1}$ & TGW & BY & GY & HI \\
\hline VD & 1 & & & & & & & & & \\
\hline $\mathrm{RD}$ & $0.95 * *$ & 1 & & & & & & & & \\
\hline $\mathrm{LC}$ & $0.99 * *$ & $0.96 * *$ & 1 & & & & & & & \\
\hline $\mathrm{Tm}^{-2}$ & $0.68 * *$ & $0.76 * *$ & $0.69 * *$ & 1 & & & & & & \\
\hline $\mathrm{Sm}^{-2}$ & $0.81 * *$ & $0.85 * *$ & $0.82 * *$ & $0.98 * *$ & 1 & & & & & \\
\hline $\mathrm{GS}^{-1}$ & $0.82 * *$ & $0.88 * *$ & $0.82 * *$ & $0.94 * *$ & $0.96 * *$ & 1 & & & & \\
\hline TGW & $0.93 * *$ & $0.92 * *$ & $0.93 * *$ & $0.88 * *$ & $0.95 * *$ & $0.93 * *$ & 1 & & & \\
\hline BY & $0.79 * *$ & $0.80 * *$ & $0.79 * *$ & $0.94 * *$ & $0.97 * *$ & $0.93 * *$ & $0.94 * *$ & 1 & & \\
\hline GY & $0.74 * *$ & $0.75 * *$ & $0.74 * *$ & $0.95 * *$ & $0.96 * *$ & $0.92 * *$ & $0.92 * *$ & $0.99 * *$ & 1 & \\
\hline $\mathrm{HI}$ & $0.91 * *$ & $0.93 * *$ & $0.92 * *$ & $0.90 * *$ & $0.97 * *$ & $0.93 * *$ & $0.99 * *$ & $0.95 * *$ & $0.92 * *$ & 1 \\
\hline
\end{tabular}

*,** Significant at 5 and $1 \%$ probability, respectively

EM (days from sowing to emergence), VD (days from emergence to flowering), RD (days from flowering to physiological maturity), LC (total crop life cycle), $\mathrm{Tm}^{-2}\left(\right.$ tillers $\left.\mathrm{m}^{-2}\right), \mathrm{Sm}^{-2}\left(\right.$ spike $\left.\mathrm{m}^{-2}\right), \mathrm{GS}^{-1}$ (grain spike ${ }^{-1}$ ), TGW (thousand grain weight), BY (biological yield), GY (grain yield) and HI (harvest index)

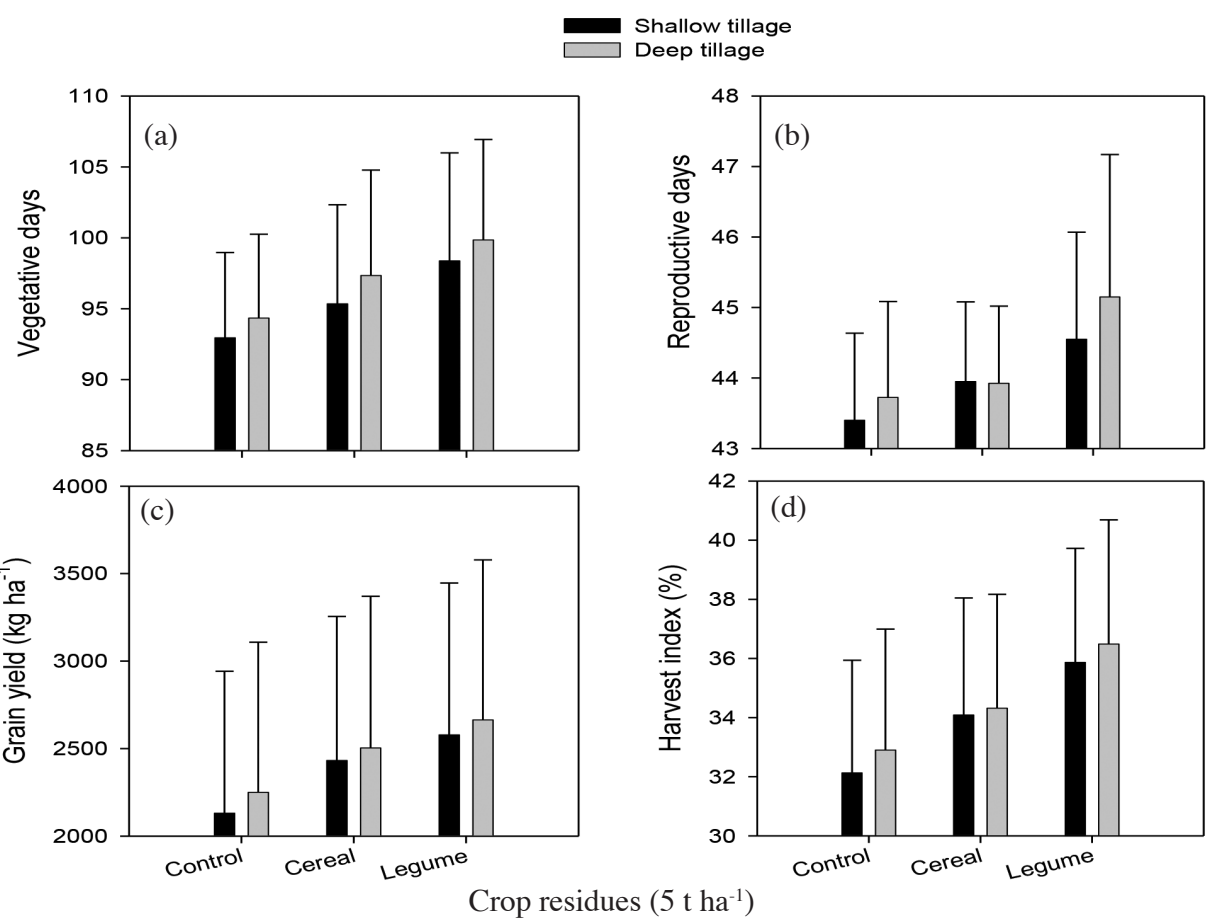

FIGURE 1. Interaction of crop residue and tillage for (a) vegetative days, (b) reproductive days, (c) grain yield and (d) harvest index of wheat in 2009-2010 and 2010-2011

treatments (crop residue $\times \mathrm{N}$ ) for the different parameters found significant are shown in Figure 2. The VD, RD and LC showed a moderate to mild increasing trend for all the three residue treatments when $\mathrm{N}$ increased from 0 to $160 \mathrm{~kg} \mathrm{ha}^{-1}$. Nonetheless, no residue with cereal residue treatments was found the same at the highest N. Contrary to that, either residue did not differ at control but legume residue enhanced $\mathrm{RD}$ at any rate of $\mathrm{N}$ application while cereal with no residue treatments did not differ at any $\mathrm{N}$ application rates. The crop LC did differ at any stage from control to any increments of $\mathrm{N}$ application with lowest for the no residue, higher for the cereal and the highest for the legume residue application to wheat crop. Among the yield trait interaction, spike number than tillers showed a clear difference at no $\mathrm{N}$ between no residue and likewise between cereal and legume residue application, which enhanced at a significant rates with increasing $\mathrm{N}$ application rates. These differences were found among the residue at any $\mathrm{N}$ application rates. Grain weight was enhanced with increasing $\mathrm{N}$ but was found different in fashion when compared between the residues and/or with no residue at a given rate of $\mathrm{N}$ application. Control (no residue) did not 


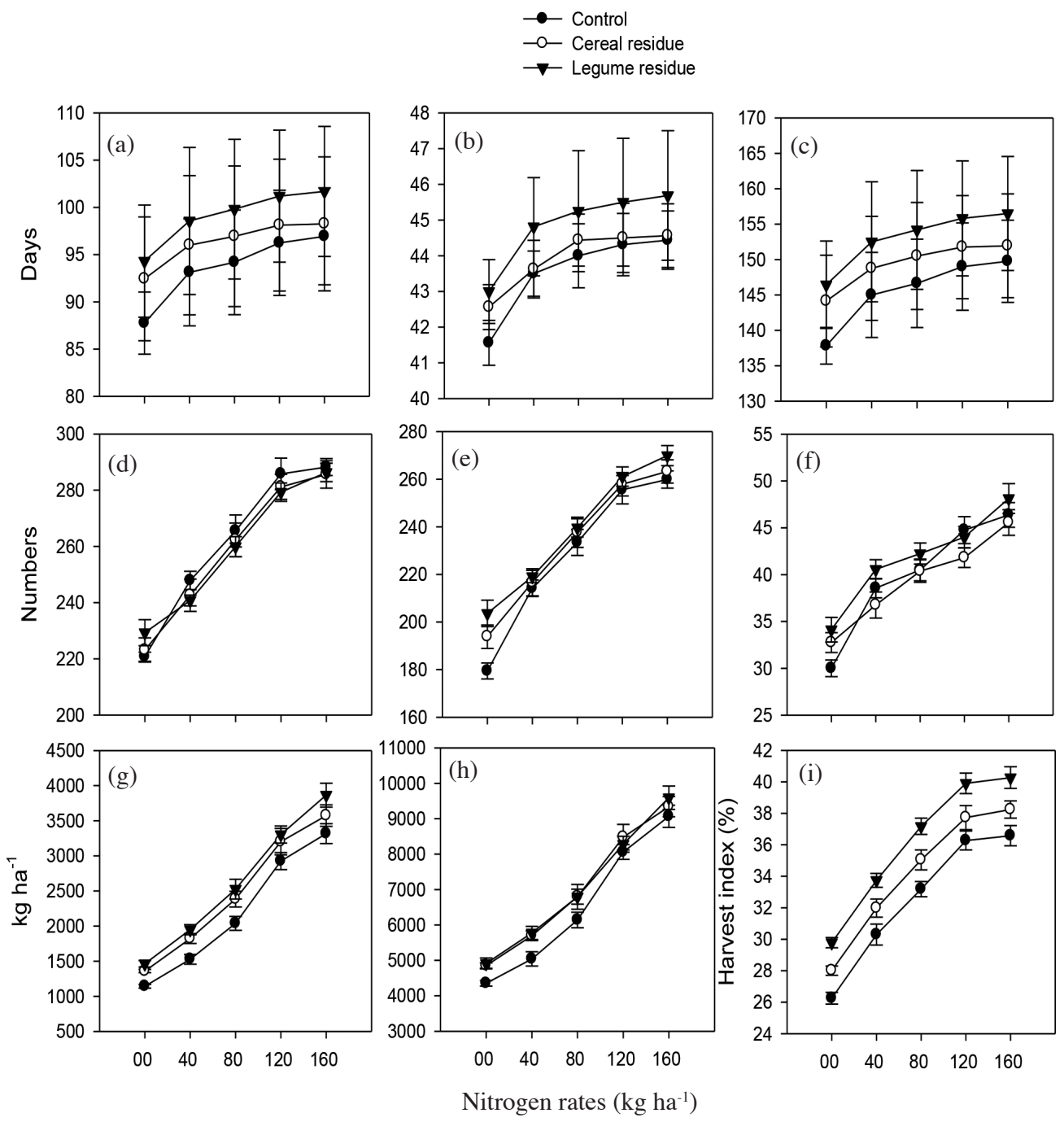

FIGURE 2. Interaction of nitrogen rates and crop residues for (a) vegetative days, (b) reproductive days,

(c) life cycle, (d) tillers $\mathrm{m}^{-2}$, (e) spikes $\mathrm{m}^{-2}$, (f) grains spike ${ }^{-1}$, (g) grain yield, (h) biological yield and (i) harvest index of wheat in 2009-2010 and 2010-2011

show a matching grain yield with cereal and/or legume residue at any given rate of the $\mathrm{N}$ application including control treatment. Biological yield did not differ between residues but was found lower at no residue in control and at any given $\mathrm{N}$ rate to the crop. Harvest indices showed a clear visible increasing trend among the no residue, followed by cereal and the highest for the legume residue. The 140 and $160 \mathrm{~kg} \mathrm{ha}^{-1}$ did not show any significant change among the three residue treatments. Tillage with $\mathrm{N}$ interaction was also found significant for different observations with higher for deep than shallow tillage at any $\mathrm{N}$ rate (Figure 3 ). The crop VD and LC showed a uniform difference between both tillage systems at any $\mathrm{N}$ applications. Contrary to this, grain and biological yields as well as harvest index showed a significant increase at any increment of applied $\mathrm{N}$ with minute to moderate differences between the two tillage systems. Three factor interaction (tillage $\times$ crop residue $\times$ nitrogen rates) also showed significant responses for RD, grain weight, grain and biological yield and harvest index (Figure 4). The RD showed differences among residue treatments at shallow tillage with almost similar trends for no residue at any $\mathrm{N}$ application rates. Cereal than legume under the deep tillage was observed higher at any N. Grain number also varied among residue than no residue treatment under shallow and deep tillage in similar fashion with increased in $\mathrm{N}$ rates. Similarly, the residue was not found comparable with no residue at any $\mathrm{N}$ rates either in shallow or deep tillage for biological yield. The harvest indices showed clear variations among the treatments when $\mathrm{N}$ was increased from 0 to $160 \mathrm{~kg} \mathrm{ha}^{-1}$ for both tillage systems but with remarkable differences under the shallow system at 140 and $160 \mathrm{~kg} \mathrm{ha}^{-1}$ as compared to the deep tillage systems.

\section{DISCUSSION}

Residue decomposition in soil is a natural but slow process. It takes time to be made available to plant and 

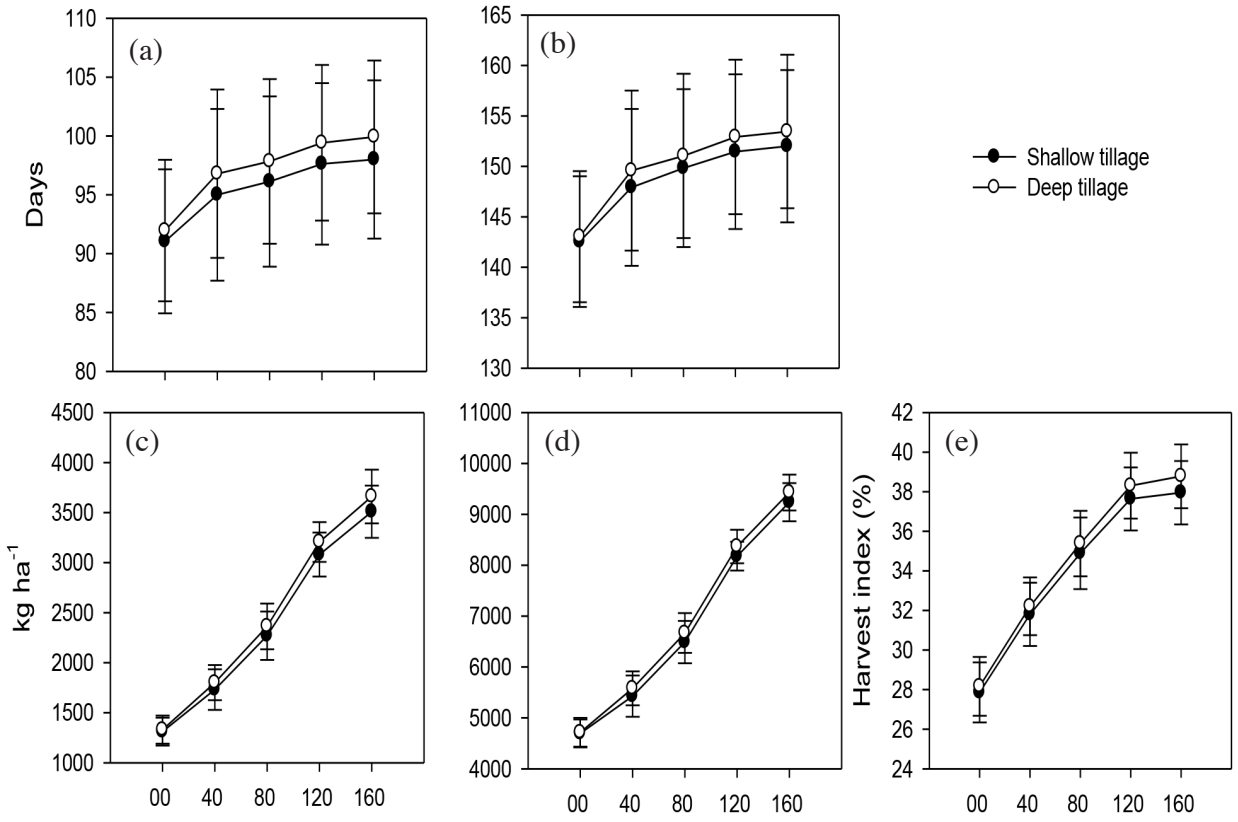

Nitrogen rates $\left(\mathrm{kg} \mathrm{ha}^{-1}\right)$

FIGURE 3. Interaction of nitrogen rates and tillage for (a) vegetative days, (b) life cycle, (c) grain yield,

(d) biological yield and (e) harvest index of wheat in 2009-2010 and 2010-2011
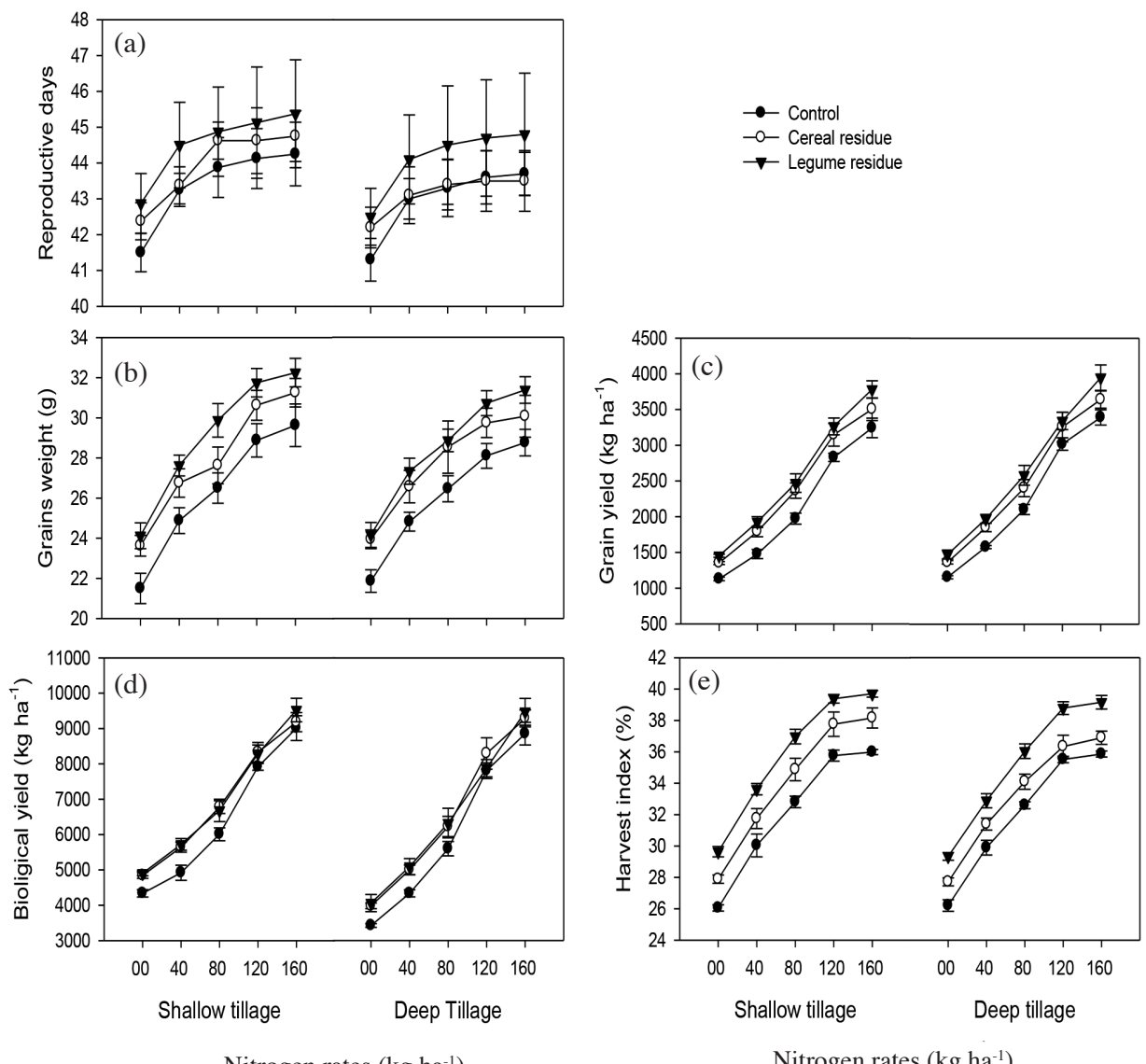

Nitrogen rates $\left(\mathrm{kg} \mathrm{ha}^{-1}\right)$

Nitrogen rates $\left(\mathrm{kg} \mathrm{ha}^{-1}\right)$

FIGURE 4. Interaction of nitrogen rates, tillage and crop residues for (a) reproductive days, (b) grain weight,

(c) grain yield, (d) biological yield and (e) harvest index of wheat in 2009-2010 and 2010-2011 
improve performance of the soil microbes. Rate of residue decomposition in soil has a close association with the amount of soil nitrogen (Sierra \& Motisi 2012). The process of decomposition starts with liberation of $\mathrm{CO}_{2}$ and $\mathrm{H}_{2} \mathrm{O}$ into organic combinations and formation of new compounds. Organisms responsible for the decomposition of residue, other than essential elements, needs $\mathrm{N}$ and $\mathrm{C}$. Low $\mathrm{N}$ soil has slow down the decomposition process (Md-Alamgir et al. 2012). It is, therefore, essential to sustain a desired C:N through residue incorporation (Sierra $\&$ Motisi 2012). Cereal vs. legume had higher C:N and likewise cereal vs. no-residue. We observed a higher yield with healthier traits under legume residue than cereal and in cereal than the no-residue treatments. Consecutive residue incorporation for two seasons with increasing $\mathrm{N}$ rate has also sustained a better $\mathrm{C}: \mathrm{N}$ which probably has resulted in better yield performance of the second season than the first and/or two year average data. Under a semi permanent cereal-based cropping system, $\mathrm{C}: \mathrm{N}$ is expected to disturb that may show a reduction in soil macro- and/or micro nutrients to express under the optimum applied rate of fertilizer (Youjun \& Ming 2011). Cowpea incorporated as legume residue had shown favorable effects $(p<0.05)$ over the cereal and/or cereals from no-residue treatments on yield traits that resulted better dry matter and grain yield (Maskina et al. 1993).

Compared to the year 1, we noticed better yield and yield traits in year 2. It might be possible that fresh residues has decomposed faster but not necessary advantageous for the growing crop right after their application of either legume or cereal nature (Youjun \& Ming 2011). Rate of degradation of the crop residue into organic matter (OM) varies from months in non-humic substance to years in the humic-substance (Sierra et al. 2010). Crop VD increased under application of $\mathrm{N}$ rates. More days taken by a crop to reach anthesis could be easily correlated with continuous cell division and multiplication under the optimum nitrogen, which may have prolonged vegetative phase of development (Hameed et al. 2003). The more days to anthesis can also favor the extended leaf area duration and a better vegetative growth as reported for total biomass. It is advantageous for the crop to utilize the radiation efficiently for biomass production (Delden 2001). Longer RD correlates to higher $\mathrm{N}$ application. It may have delayed senescence and/or sustained photosynthate long by resulting healthy grain (Frederick \& Camberato 1995). It is known that the number of days to physiological maturity under higher $\mathrm{N}$ is important for better grain filling duration (Ayub et al. 2002). We also noted a linear increase in VD and RD by increased $\mathrm{N}$ from 0 to $160 \mathrm{~kg} \mathrm{ha}^{-1}$. Long VD with high $\mathrm{N}$ might have converted carbohydrates rapid to protein, which has resulted increase in cell size (Bundy \& Andraski 2004; Deng et al. 2004). Optimum utilization of $\mathrm{N}$ had already shown increment in grain number due to transition of carbohydrates in phloem with rapid increase in cell division (Tabatabaii et al. 2011). Optimum $\mathrm{N}$ had also increased protein, which showed positive response on grain weight (Guenis et al. 2003; Kausar et al. 1993).

\section{CONCLUSION}

Compared to the 1st year crop, the 2nd year crop showed more profound treatment's effect on crop establishment and yield. It can be said that legume residue (LR) incorporation at $5 \mathrm{tha}^{-1}$ had improved the life cycle and hence the grain yield. Deep-over the shallow tillage system had beneficial to improve relatively better crop yield. Residue with higher $\mathrm{N}$ had shown lasting effect on the crop grown. Legume residue incorporated with a deep plow (Cultivator) and 120 $\mathrm{kg} \mathrm{N}^{-1}$ showed better response than cereal residue with $160 \mathrm{~kg} \mathrm{ha}^{-1}$ and/or control (no residue) with the highest $\mathrm{N}$ application of the cropping system. Thus, incorporation of legume residues with deep plow and relatively lower $\mathrm{N}$ application $\left(120 \mathrm{~kg} \mathrm{ha}^{-1}\right)$ is more advantageous to sustain soil fertility and crop productivity.

\section{ACKNOWLEDGEMENTS}

The authors acknowledged the financial support from the Higher Education Commission (HEC) of Pakistan for the living and research as indigenous fellowship to obtain higher education. The authors also acknowledged the SAS facility used at Hasting Electronic Learning Centre (HELC), West Texas A\&M University, USA.

\section{REFERENCES}

Ayub, M., Nadeem, M.A., Sharar, M.S. \& Mahmood, N. 2002. Response of maize (Zea mays L.) fodder to different levels of nitrogen and phosphorus. Asian Journal of Plant Science 1: 352-354.

Bhagat, R.M. 1990. Effect of tillage and residues management on hydrothermal regime, nutrient uptake and yield of wheat in a river deposit. Soil and Tillage Research 9: 315-326.

Brown, L.R. 1999. Feeding nine billion. In State of the World, edited by Brown, L.R., Flavin, C. \& French, H. New York: W. Norton \& Co. pp. 115-132.

Bundy, L.G. \& Andraski, T.W. 2004. Diagnostic tests for site-specific nitrogen recommendations for winter wheat. Agronomy Journal 96: 608-614.

Delden, V.A. 2001. Yield and growth components of potato and wheat under organic nitrogen management. Agronomy Journal 93: 1370-1385.

Deng, S., Stein, R.A. \& Higgins, N.P. 2004. Transcription-induced barriers to supercoil diffusion in the Salmonella typhimurium chromosome. Proceedings of the National Academy of Sciences USA 101: 3398-3403.

Edwards, W. 2007. Estimating a value for corn stover. Ag decision maker. Department of Economics, University Extension, Iowa State University. File A1-70: 1-4.

ESP. 2012. Economic survey of Pakistan. Highlights of the Pakistan economic survey 2011-12. Economic adviser's wing, finance division, Government of Pakistan, Islamabad. pp. 1-18.

FAO. 2009. Food and Agriculture Organization, FAOSTAT data, 2009-last updated 20 December, 2008. Rome.

FAOSTAT. 2012. Food and Agriculture Organization of United Nations. Rome. http://faostat.fao.org. (verified Apr. 3, 2012).

Fillery, I.R.P. 2001. The fate of biologically fixed nitrogen in legume-based dryland farming systems: A review. Australian Journal of Experimental Agriculture 41: 361-381. 
Frederick, J.R. \& Camberato, J.J. 1995. Water and nitrogen effects on winter wheat in the southeastern coastal plain: II- Physiological responses. Agronomy Journal 4: 241-248.

Guenis, A., Alpaslan, M. \& Unal, A. 2003. Effects of boron fertilization on the yield and some yield components of bread and durum wheat. Turkish Journal of Agriculture 27: 329-335.

Hameed, E., Shah, W.A., Shad, A.A., Bakht, J. \& Muhammad, T. 2003. Effect of different planting dates, seed rates and nitrogen levels on wheat. Asian Journal of Plant Science 2(6): 464-474.

Hofstrand, D. 2009. Crop residue - a valuable resource. Agricultural marketing resource center. Renewable Energy Newsletter. pp. 1-5.

IFOAM. 2012. International Federation of Organic Agriculture Movements. www.ifoam.org. (verified Apr. 3, 2012)

Karlen, D.L., Dinnes, D.L., Tomer, M.D., Meek, D.W., Cambardella, C.A. \& Moorman, T.B. 2009. Is no-tillage enough? A field-scale watershed assessment of conservation effects. Electronic Journal of Integrative Biosciences 7(2): $1-24$.

Kausar, K., Akbar, M., Rasul, E. \& Ahmad, A.N. 1993. Physiological responses of nitrogen, phosphorus and potassium on growth and yield of wheat. Pakistan Journal of Agriculture Research 14: 2-3.

Maskina, M.S., Power, J.F., Doran, J.W. \& Wilhelm, W. 1993. Residual effects of no-till crop residues on corn yield and nitrogen uptake. American Journal of Soil Science Society 57: 1555-1560.

Md-Alamgir, McNeill, A., Tang, C. \& Marschner, P. 2012. Changes in soil P pools during legume residue decomposition. Soil Biological Biochemistry 49: 70-77.

Mosier, A.R., Bleken, M.A., Chaiwanakupt, P., Ellis, E.C., Freney, J.R., Howarth, R.B., Matson, P.A., Minami, K., Naylor, R., Weeks, K.N. \& Zhu, Z. 2001. Policy implication of human accelerated nitrogen cycling. Biogeochemistry 52: $281-320$

Pathak, H., Ladha, J.K., Aggarwal, P.K., Peng, S., Das, S., Singh, Y., Singh, B., Kamra, S.K., Mishra, B., Sastri, A.S.R.A.S., Aggarwal, H.P., Das, D.K. \& Gupta, R.K. 2003. Trends of climatic potential and on-farm yields of rice and wheat in the Indo-Gangetic Plains. Field Crops Research 80(3): 223-234.

SAS Institute. 2011. Statistical Analysis System. User's Guide, Version 9.3, Cary, NC, USA.

Sierra, J., Brisson, N., Ripoche, D. \& Déqué, M. 2010. Modeling the impact of thermal adaptation of soil microorganisms and crop system on the dynamics of organic matter in a tropical soil under a climate change scenario. Ecological Modeling 221: $2850-2858$

Sierra, J. \& Motisi, N. 2012. Shift in C and N humification during legume litter decomposition in an acid tropical Ferralsol. Soil Research 50: 380-389.
Silvester-Bradley, R. 1993. Scope for more efficient use of fertilizer nitrogen. Soil Use Manage 9: 112-117.

Smil, V. 2011. Nitrogen cycle and world food production. World Agriculture 2: 9-1.

Smil, V. 2001. Enriching the Earth: Fritz Haber, Carl Bosch and the Transformation of World Food Production. Cambridge, MA: The MIT Press, xvii + p. 338.

Steel, R.G.D. \& Torrie, J.H. 1997. Principles and Procedures of Statistics: A Biometrical Approach. 3rd eds., New York: McGraw Hill Book Co. Inc.

Strudley, M.W., Green, T.R. \& Ascough II, J.C. 2008. Tillage effects on soil hydraulic properties in space and time: State of the science. Soil and Tillage Research 99: 4-48.

Tabatabaii, E.S., Yarnia, M., Khorshidi, B.M.B. \& Farajzadeh, M.T.E. 2011. Effect of potassium fertilizer on corn yield (Jet acv.) under drought stress condition. American-European Journal of Agriculture \& Environmental Sciences 10(2): 257-263.

Teixeira, K.J.A., Davis, S.C., Masters, M.D. \& Delucia, E.H. 2009. Changes in soil organic carbon under biofuel crops. GCB Bioenergy 1: 75-96.

Youjun, L. \& Ming, H. 2011. Effect of tillage managements on soil rapidly available nutrient content and the yield of winter wheat in West Henan Province, China. Procedia Environmental Science 11: 843-849.

UNPD. 2011. United nation population division. Department of Economic and Social Affair. Population Estimates and Projection Section. http://www.un.org/en/development/desa/ population/

UNWPP. 2012. United nation world population prospects Department of Economic and Social Affair. Population Estimates and Projection Section. http://esa.un.org/wpp/

Asad Shah*, Mohammad Akmal \& Mohammad Arif Department of Agronomy

The University of Agriculture

Peshawar-Pakistan

Mohammad Jamal Khan

Department of Soil and Environmental Science

The University of Agriculture

Peshawar-Pakistan

*Corresponding author; email: a.shah@aup.edu.pk

Received: 24 December 2013

Accepted: 30 April 2014 